\title{
Perubahan Kesiapsiagaan Masyarakat DAS Beringin Kota Semarang dalam Menghadapi Ancaman Banjir Bandang
}

\author{
Afrizal Novan Nurromansyah ${ }^{1}$ \\ Yayasan Bina Karta Lestari, Semarang, Indonesia
}

\section{Jawoto Sih Setyono}

Jurusan Perencanaan Wilayah dan Kota, Universitas Diponegoro, Semarang, Indonesia

Artikel Masuk : 23 Oktober 2014

Artikel Diterima : 19 November 2014

\begin{abstract}
Abstrak: Pada tahun 2010 terjadi banjir bandang besar di kawasan DAS Beringin Kota Semarang. Pasca kejadian tersebut, pemerintah bersama masyarakat Kota Semarang menjalankan program ketahanan kota melalui program Flood Early Warning System (FEWS) yang dilaksanakan di Kawasan DAS Beringin. Salah satu prioritas tindakannya adalah memperkuat kesiapsiagaan terhadap bencana. Penelitian ini bertujuan untuk menggambarkan perubahan upaya kesiapsiagaan yang terjadi setelah berjalannya program FEWS. Penelitian ini menggunakan pendekatan kualitatif. Metode sampling menggunakan metode purposive sampling dengan teknik analisis data menerapkan analisis deskriptif kualitatif. Hasil penelitian menunjukkan, perubahan kesiapsiagaan terjadi pada upaya pemahaman kebencanaan, mobilisasi sumber daya, sistem peringatan dini banjir bandang, dan perencanaan kesiapsiagaan. Pemahaman kebencanaan terjadi perubahan pada aspek sumber informasi pengetahuan dan aspek paradigma tindakan mitigatif bencana. Pada upaya kesiapsiagaan terkait mobilisasi sumber daya, perubahan terjadi pada aspek ketersediaan tim bencana, prosedur komando, aspek peran kelembagaan, aspek struktur kelembagaan, aspek skema komunikasi dan koordinasi, kesepakatan penggunaan alat dan manajemen komunikasi ke luar dan dalam wilayah.
\end{abstract}

Kata Kunci: Banjir bandang, DAS Beringin, Flood Early Warning System, Pengurangan Risiko Bencana Berbasis Komunitas

\begin{abstract}
In 2010 a large flash flood happened in the region of Beringin watershed in Semarang. After the disaster, The Government of Semarang City with the community ran the program namely Flood Early Warning System (FEWS) conducted in the area of Beringin watershed. One of priority actions is strengthening for disaster preparedness. This research aims to describe the change of preparedness efforts that occurs after running the program. The research uses a qualitative approach. A method of sampling is purposive sampling. The technique of data analysis use descriptive qualitative analysis. The results of research show that the change occurring in understanding disaster preparedness efforts, mobilization of resources, flash flood early warning system and preparedness planning. Disaster understanding changes in sources of information on the aspect of knowledge, and the aspect of the act of disaster mitigation paradigm. On the preparedness efforts related to the
\end{abstract}

\footnotetext{
${ }^{1}$ Korespondesi Penulis: Yayasan Bina Karta Lestari (BINTARI), Semarang

Email penulis: afrizal.novan.n@gmail.com
} 
mobilization of resources, the change happens on aspect of the availability of the disaster team, command procedures, the role of institutional aspects, the aspect of the institutional structure, the aspect of communication and coordination of the scheme, the agreement the use of tools and management of communication to the outside and in the region.

Keywords : Community Based Disaster Risk Reduction, DAS Beringin, Flash Flood, Flood Early Warning System

\section{Pendahuluan}

Perubahan iklim merupakan isu global dalam beberapa dekade terakhir. Seiring berjalannya waktu, tidak dapat dipungkiri bahwa perubahan iklim telah terjadi hampir di seluruh dunia. Terbukti dengan semakin banyaknya tanda tanda sepeti cuaca ekstrem dan pemanasan global di berbagai negara. Oleh karenanya, peubahan iklim menjadi tantangan yang harus dihadapi di era sekarang ini. Salah satu dampak perubahan iklim yang menjadi fokus oleh beberapa negara adalah mengenai kebencanaan. Kebencanaan yang terjadi di berbagai negara tidak lain juga disebabkan oleh adanya perubahan iklim. Salah satunya adalah Negara Indonesia.

Indonesia merupakan negara rawan bencana. Adanya perubahan iklim semakin berdampak pada ancaman bencana yang semakin besar. Secara gars besar, bencana adalah peristiwa atau rangkaian peristiwa yang mengancam dan mengganggu kehidupan dan penghidupan masyarakat yang disebabkan, baik oleh faktor alam dan/atau faktor nonalam maupun faktor manusia sehingga mengakibatkan timbulnya korban jiwa manusia, kerusakan lingkungan, kerugian harta benda, dan dampak psikologis (BNPB, 2007).

Bencana alam memberikan dampak kerugian yang sangat besar bagi wilayah terdampak. Kerugian fisik, dan kerugian non fisik sejalan dengan dampak terjadinya bencana alam. Kerugian fisik yang terjadi seperti kerugian kerusakan bangunan, kerusakan ekosistem, kerusakan sarana dan prasarana. Sedangkan kerugian non fisik seperti kerugian kesehatan mental dan psikis korban bencana. Dampak tersebut merata disebabkan oleh berbagai bencana alam baik itu gempa bumi, gunung meletus, tanah longsor dan banjir

Adanya permasalahan tersebut mendorong Negara Indonesia untuk melakukan tindakan tindakan mitigatif terkait isu global perubahan iklim. Dalam 'Kerangka Aksi Hyogo' tahun 2005 didapatkan tujuan strategis dan prioritas aksi terkait pengurangan risiko bencana serta meningkatkan ketahanan negara dan masyarakat tahan bencana. Kerangka Aksi Hyogo merupakan hasil dari $2^{\text {nd }}$ World Conference on Disaster Reductions yang membahas tentang isu pengurangan risiko bencana. Konferensi diikuti oleh 168 negara termasuk Indonesia dan dilaksanakan di Kobe, Jepang pada tanggal 18-22 Januari 2005. Konferensi tersebut menyepakati sebuah strategi pengurangan risiko bencana yang berjangka waktu 10 tahun dan dinamakan Kerangka Aksi Hyogo. Indonesia merupakan salah satu negara yang berkomitnen dalam mengadopsi hasil konferensi tentang mewujudkan ketahanan negara.

Dalam implementasinya, ketahanan negara perlu diwujudkan melalui pembentukan jaringan kota kota berketahanan. Beberapa kota dituntut untuk mewujudkan kota yang berketahanan salah satunya Kota Semarang. Kota Semarang merupakan salah satu kota yang menjadi program percontohan kota yang berketahanan. Program percontohan tersebut termasuk dalam project cooperation dari ACCCRN (Asian Cities Climate Change Resilient Network). ACCCRN merupakan proyek jejaring kota kota berketahanan di Asia dan merupakan bantuan dana dari The Rockefeller Foundation. ACCCRN terdapat di 10 kota Asia termasuk Indonesia sebagai salah satu Negara penerima manfaat proyek ACCCRN. ACCCRN berfokus dalam perubahan iklim, kerentanan dan kemiskinan serta 
urbanisasi. Kegiatan ACCCRN Indonesia diawali pada bulan Juni tahun 2009 hingga sekarang (2014). Salah satu program dari ACCCRN adalah Flood Early Warning System (kemudian disebut FEWS) di DAS Beringin Semarang. Pemilihan lokasi program FEWS di DAS Beringin berdasarkan atas terjadinya bencana banjir bandang dahsyat pada tahun 2010 di DAS Beringin. Program FEWS bertujuan untuk mewujudkan system peringatan dini banjir. Program tersebut yang menjadi program percontohan dalam mewujudkan ketahanan kota

Program tersebut didasarkan pada terjadinya bencana banjir bandang di DAS Beringin pada tahun 2010. Dalam sejarahnya, bencana banjir berulang kali terjadi di DAS Beringin dengan bencana terbesar terjadi pada tahun 2010. Banjir pada tahun 2010 memiliki karakteristik banjir bandang dan berbeda dengan banjir sebelumnya. Sebelumnya banjir pernah terjadi pada tahun 1992, 2000, dan 2002. Perbedaannya, banjir yang terjadi sebelum tahun 2010 bersifat genangan banjir dan merendam di bagian hilir sungai yaitu Kelurahan Mangunharjo, Kelurahan Mangkang Wetan, dan Kelurahan Wonosari. Selain itu ketinggian banjir tidak mencapai level 2 meter dari permukaan tanah. Dampak yang ditimbulkan berupa kerusakan fisik dan non fisik. Banjir yang terjadi disebabkan oleh tingginya intensitas hujan dalam waktu lama. Berbeda dengan banjir yang terjadi pada tahun 2010. Karakteristik banjir tergolong banjir bandang dengan area terdampak tidak hanya di bagian hilir tetapi juga melingkupi bagian hulu sungai tepatnya di Kelurahan Wates. Ketinggian air mencapai 3 meter di atas permukaan tanah dan menelan korban jiwa sebanyak 8 orang. Penyebab terjadinya banjir tidak hanya intensitas hujan tetapi juga akibat alihfungsi lahan, sedimentasi sungai dan adanya pengaruh perubahan iklim.

Besarnya dampak yang ditimbulkan membuat Pemerintah Kota Semarang memprioritaskan tindakan memperkuat kesiapsiagaan terhadap bencana. Dengan tingginya kesiapsiagaan masyarakat maka akan mengurangi risiko bencana yang ditimbulkan. Memperkuat kesiapsiagaan menjadi prioritas karena kesiapsiagaan masyarakat pada banjir banjir sebelumnya (sebelum tahun 2010) dirasa masih kurang dan hanya bersifat personal sehingga dampak kerusakan fisik dan korban jiwa cukup banyak. Personal diartikan kesiapsiagaan hanya di tingkat rumah tangga tanpa melibatkan sistem evakuasi (membangun tataban di rumah masing masing) dan mekanisme komunikasi secara keseluruhan.

Dalam implementasi program FEWS, dibentuk kelompok siaga bencana di ketujuh kelurahan. Ketujuh kelompok siaga bencana mendapatkan pelatihan pengurangan risiko bencana berbasis komunitas diantaranya upaya upaya kesiapsiagaan bencana. Upaya kesiapsiagaan pasca berjalannya program menjadi hal yang perlu dieksplorasi mengingat upaya kesiapsiagaan pasca program berjalan jauh berbeda dengan upaya kesiapsiagaan sebelum adanya program. Sebelum adanya program kesiapsiagaan lebih bersifat personal, selain itu sistem peringatan bersifat tradisional. Perbedaan upaya kesiapsiagaan setelah masuknya program FEWS dengan sebelum adanya program memunculkan pertanyaan Apa perubahan upaya kesiapsiagaan masyarakat yang terbentuk setelah berjalannya program Flood Early Warning System?

\section{Kajian Literatur}

Kesiapsiagaan merupakan salah satu bagian dari proses manajemen bencana dan di dalam konsep pengelolaan bencana yang berkembang saat ini, peningkatan kesiapsiagaan merupakan salah satu elemen penting dari kegiatan pengurangan risiko bencana yang bersifat pro-aktif, sebelum terjadinya suatu bencana. Dalam kajian untuk pengembangan kerangka penilaian kesiapsiagaan masyarakat, digunakan suatu konsep atau pengertian dari Carter (1991) yaitu tindakan-tindakan yang memungkinkan pemerintahan, organisasi 


\section{Perubahan Kesiapsiagaan Masyarakat DAS Beringin Kota Semarang...}

organisasi, masyarakat, komunitas dan individu untuk mampu menanggapi suatu situasi bencana secara cepat dan tepat guna. Termasuk ke dalam tindakan kesiapsiagaan adalah penyusunan rencana penanggulangan bencana, pemeliharaan sumberdaya dan pelatihan personil.

Dengan demikian kesiapsiagaan bisa diartikan sebagai: Kesiapan masyarakat di semua lapisan untuk mengenali ancaman yang ada di sekitarnya serta mempunyai mekanisme dan cara untuk menghadapi bencana. Kesiapsiagaan dilakukan tahapan PB dan bertujuan untuk membangun kapasitas yang diperlukan untuk secara efektif mampu mengelola segala macam keadaan kedaruratan dan menjembatani masa transisi dari respon ke pemulihan yang berkelanjutanBila dilihat dari istilahnya dan berdasarkan pada jenis, waktu dan tujuan aktivitasnya, kesiapsiagaan merupakan gabungan dari dua istilah yang berbeda

Dalam kesiapsiagaan bencana ini, terdapat 9 kegiatan yang bisa dilakukan, yaitu

1. Penilaian terhadap bahaya, risiko, dan kerentanan.

2. Penyusunan strategi dan mekanisme tanggap darurat

3. Penyusunan rencana kesiapsiagaan

4. Koordinasi di antara para pihak dan pemangku kepentingan yang terlibat dalam proses

5. Pengelolaan informasi sehingga para pihak dan pemangku kepentingan mampu mengetahui perkembangan yang terjadi

6. Sistem peringatan dini

7. Mobilisasi sumberdaya, baik manusia, material, keuangan maupun pengetahuan

8. Pendidikan kepada masyarakat, termasuk di dalamnya pelatihan dan uji coba atau simulasi

9. Membangun kesiapsiagaan berbasis masyarakat

Kesiapsiagaan suatu komunitas selalu tidak terlepas dari aspek-aspek lainnya dari kegiatan pengelolaan bencana (tanggap darurat, pemulihan dan rekonstruksi, pencegahan dan mitigasi). Untuk menjamin tercapainya suatu tingkat kesiapsiagaan tertentu, diperlukan berbagai langkah persiapan pra-bencana, sedangkan keefektifan dari kesiapsiagaan masyarakat dapat dilihat dari implementasi kegiatan tanggap darurat dan pemulihan pasca bencana. Pada saat pelaksanaan pemulihan dan rekonstruksi pasca bencana, harus dibangun juga mekanisme kesiapsiagaan dalam menghadapi kemungkinan bencana berikutnya.

\section{Metode Penelitian}

Metodologi penelitian adalah tata cara bagaimana suatu penelitian dilaksanakan (Iqbal Hasan, 2002:21). Dalam metodologi penelitian membicarakan tentang filsafat ilmu yaitu apakah ilmu dan mengapa orang melakukan penelitian, prosedur penelitian mencakup pembahasan bagaimana suatu penelitian dimulai dan diakhiri serta alat analisis.

Penelitian ini bertujuan untuk menggambarkan perubahan upaya upaya kesiapsiagaan masyarakat setelah adanya program Flood Early Warning System. Penggambaran perubahan upaya kesiapsiagaan lebih eksploratif dan mendalam serta menggambarkan realitas suatu kasus yang memiliki permasalahan yang kompleks. Oleh karenanya, pendekatan penelitian yang sesuai digunakan dalam penelitian ini adalah pendekatan kualitatif.

Dalam penelitian ini, intrumen yang digunakan yaitu (Form wawancara, Alat perekam, Kamera, Alat tulis, Komputer). 
Penentuan teknik sampling menggunakan tenik non probability sampling dengan metode sampling menggunakan purposive sampling. Dalam pelaksanaan pengumpulan data, sampel dipilih peneliti. Pemilihan sampel didasarkan atas beberapa kriteria di bawah ini:

1. Menguasai dan memahami permasalahan

2. Tergolong masih sedang terlibat pada kegiatan yang tengah diteliti dan berada dalam kelompok terdampak.

3. Narasumber memiliki waktu yang memadai

4. Narasumber tidak cenderung menyampaikan informasi hasil 'kemasannya' sendiri

Sesuai dengan kriteria di atas didapatkan kemungkinan nama narasumber yang akan dijadikan sampel yakni dilihat pada Tabel 1 .

Tabel 1. Narasumber Penelitian

\begin{tabular}{l|l|l}
\hline No & \multicolumn{1}{|c}{ Narasumber } & \multicolumn{1}{c}{ Posisi } \\
\hline 1 & Pak Faidzin & Ketua KSB Wates \\
\hline 2 & Pak Khaerohman & Ketua KSB Wonosari \\
\hline 3 & Pak Imron & Ketua KSB Mangunharjo \\
\hline 4 & Yuliana Rachmawati & Koordinator Bidang Community Development \\
\hline 5 & Pak Soleh & Warga Kelurahan Wates \\
\hline 6 & Ibu Muslimah & Warga Kelurahan Wonosari \\
\hline
\end{tabular}

Analisis yang digunakan adalah analisis deskripstif kualitatif. Adapun proses analisis yang dilakukan dalam penelitian ini yaitu:

1. Identifikasi Sistem Peringatan Dini Banjir

Dalam variabel sistem peringatan dini banjir, analisis yang dilakukan adalah mengenai ketersediaan teknologi sistem peringatan bencana, ketersediaan kesepakatan peringatan dini, dan ketersediaan sistem peringatan dini tradisional

2. Identifikasi Pemahaman Kebencanaan

Dalam variabel pemahaman kebencanaan, analisis yang dilakukan mengenai ketersediaan dokumen penilaian bahaya dan risiko, ketersediaan panduan tentang pengurangan risiko bencana, dan pemahaman tentang bencana banjir bandang

3. Identifikasi Mobilisasi Sumber Daya

Dalam variabel mobilisasi sumber daya, analisis yang dilakukan mengenai ketersediaan prosedur memobilisasi sumber daya dari dalam, ketersediaan protokol untuk komunikasi dan koordinasi antar instansi dan lembaga pemerintahan, dan keteresediaan prosedur penyebarluasan peringatan bencana

4. Identifikasi Perencanaan Kesipsiagaan

Dalam variabel perencanaan kesiapsiagaan, analisis yang dilakukan mengenai, ketersediaan rencana penyelamatan dan evakuasi, dan ketersediaan rencana pertolonga pertama.

\section{Temuan Penelitian}

\section{Pemahaman Kebencanaan}

Berdasarkan hasil wawancara menunjukkan bahwa pada dasarnya masyarakat mengetahui pengetahuan banjir bandang menurut sudut pandang mereka sendiri. Seperti hasil wawancara dengan Ketua KSB Wates yaitu Pak Faizin mendeskripsikan banjir 


\section{Perubahan Kesiapsiagaan Masyarakat DAS Beringin Kota Semarang...}

bandang adalah banjir yang datang secara tiba tiba dan efeknya lebih parah. Pengertian tersebut dikuatkan oleh Pak Saheri selaku Ketua KSB Beringin yang mendeskripsikan banjir bandang adalah banjir yang tidak terencana dan datangnya tiba tiba. Namun ada pula perbedaan deskripsi mengenai banjir bandang. Menurut Pak Imron selaku Ketua KSB Mangunharjo banjir bandang adalah luapan air sungai akibat tanggul yang jebol kalau banjir biasa tidak diakibatkan oleh tanggul yang jebol. Fakta tersebut menunjukkan bahwa KSB mengetahui banjir bandang namun kurang begitu memahami secara mendalam mengenai banjir bandang. Sebagian besar masyarakat mengartikan bencana banjir bandang hanya sebatas banjir yang berlangsung dengan cepat dan deras. Fakta tersebut jika dilihat dari segi pengertian, berbeda jika dilihat dari segi lainnya.

Sebagian kecil warga kurang begitu ingat tentang sejarah banjir bandang. Beberapa narasumber menyebutkan bahwa kejadian bencana banjir bandang pernah terjadi sebelumnya, namun tidak ingat pada tahun berapa kejadian berlangsung (temuan wawancara KSB Wates). Berbeda dengan KSB Mangunharjo (Pak Imron) yang menjelaskan jika banjir bandang sebelumnya pernah terjadi pada tahun 1980 sedangkan banjir yang terjadi sesudahnya hingga sebelum tahun 2010 merupakan banjir biasa (tidak banjir bandang) akibat luapan kali beringin. Bahkan Pak Imron mendeskripsikan kategori banjir di wilayahnya.

KSB mengalami beberapa perubahan setelah adanya program FEWS. Ditinjau dari segi sumber informasi pengetahuan KSB mendapatkan informasi yang valid dari berbagai panduan ilmiah dan dari pakar / praktisi di bidangnya. Berbeda dengan kondisi sebelum adanya program FEWS, masyarakat mendapatkan informasi dari observasi fenomena (ilmu titen). Ditinjau dari segi paradigma tindakan mitigaif bencana, KSB mengalami peningkatan menuju tindakan mitigatif non struktural (kesiapsiagaan), walaupun tetap menjalankan tindakan migatif struktural. Ditinjau dari kapasitas pengetahuan, KSB mendapat peningkatan pengetahuan. KSB menjadi lebih mengerti mengani manajemen bencana berbasis masyarakat. Sehingga dapat disimpulkan bahwa terjadi perubahan mengenai pengetahuan banjir bandang KSB setelah berjalannya program. Adapun poin poin perubahan dapat dilihat pada Tabel 2 .

Tabel 2. Poin Perubahan Variabel Pemahaman Kebencanaan

\begin{tabular}{c|l|ll|l}
\hline No & \multicolumn{1}{|c|}{ Aspek } & \multicolumn{1}{c}{ Pra-Program } & \multicolumn{1}{c}{ Pasca-Program } \\
\hline 1 & $\begin{array}{l}\text { Kapasitas } \\
\text { Pengetahuan }\end{array}$ & $\bullet \begin{array}{l}\text { Belum begitu mengerti } \\
\text { mengenai upaya kesiapsiagaan }\end{array}$ & $\begin{array}{l}\text { KSB menjadi mengerti mengenai } \\
\text { upaya kesiapsiagaan. }\end{array}$ \\
\hline 2 & $\begin{array}{l}\text { Sumber } \\
\text { pengetahuan }\end{array}$ & $\bullet \begin{array}{l}\text { Otodidak, mencari sendiri } \\
\text { melalui literatur } \\
\text { Ilmu titen /observasi fenomena } \\
\text { yang telah terjadi }\end{array}$ & $\begin{array}{l}\text { Panduan / kajian ilmiah } \\
\text { Praktisi dan pakar di bidangnya }\end{array}$ \\
\hline 3 & $\begin{array}{l}\text { Paradigma } \\
\text { tindakan mitigatif }\end{array}$ & $\begin{array}{l}\text { Tindakan mitigatif secara } \\
\text { struktural }\end{array}$ & $\begin{array}{l}\text { Tindakan mitigatif struktural dan } \\
\text { non struktural }\end{array}$ \\
\hline 4 & $\begin{array}{l}\text { Pengetahuan } \\
\text { penilaian risiko }\end{array}$ & $\begin{array}{l}\text { KSB belum terlalu mengerti } \\
\text { definisi risiko }\end{array}$ & $\begin{array}{l}\text { KSB mengetahui definisi risiko } \\
\text { KSB telah melakukan kegiatan } \\
\text { penilaian risiko bencana banjir } \\
\text { bandang }\end{array}$ \\
\hline 5 & $\begin{array}{l}\text { Ketersediaan } \\
\text { dokumen } \\
\text { penilaian risiko }\end{array}$ & $\bullet \begin{array}{l}\text { Belum tersedia dokumen } \\
\text { penilaian risiko }\end{array}$ & $\begin{array}{l}\text { Telah tersedia dokumen penilaian } \\
\text { risiko berupa peta risiko } \\
\text { terdampak }\end{array}$ \\
\hline 6 & $\begin{array}{l}\text { Proses penilaian } \\
\text { risiko }\end{array}$ & $\bullet \begin{array}{l}\text { Belum ada tindakan penilaian } \\
\text { risiko }\end{array}$ & $\begin{array}{l}\text { KSB melakukan kegiatan } \\
\text { penilaian risiko melalui susur } \\
\text { sungai dan pemetaan risiko banjir } \\
\text { bandang }\end{array}$ \\
\hline
\end{tabular}




\section{Mobilisasi Sumber Daya}

Pada saat banjir tahun 2010, sebagian besar wilayah belum memiliki tim tanggap darurat kecuali di wilayah Kelurahan Wonosari. Saat itu, Kelurahan Wonosari telah memiliki tim penanggulangan bencana yang anggota didalamnya ialah para pemangku wilayah dan beberapa relawan pemuda ( wawancara KSB Wonosari). Saat bencana tahun 2010, sistem kelembagaan kebencanaan belum terbentuk sempurna. Komando berada di tangan pemangku wilayah, tokoh masyarakat, bahkan ada yang bergerak sendiri sendiri (wawancara KSB Wates, Mangunharjo, Wonosari). Sistem belum terorganisir dan tertata dengan baik (wawancara KSB Wates). Pengelolaan sumber daya belum sempurna dengan manajemen kurang bagus. Kurangnya proses tersebut mempengaruhi beberapa hal diantaranya distribusi logistik, kebutuhan dasar, pengungsian dan sistem komando. Distribusi logistik belum sempurna, kebutuhan dasar pengungsi belum terakomodasi dengan baik, dan sistem komando kurang terorganisir yang mengakibatkan kebingungan masyarakat. Secara garis besar, kelembagaan yang terbentuk saat banjir tahun 2010 dapat dilihat pada Gambar 1.

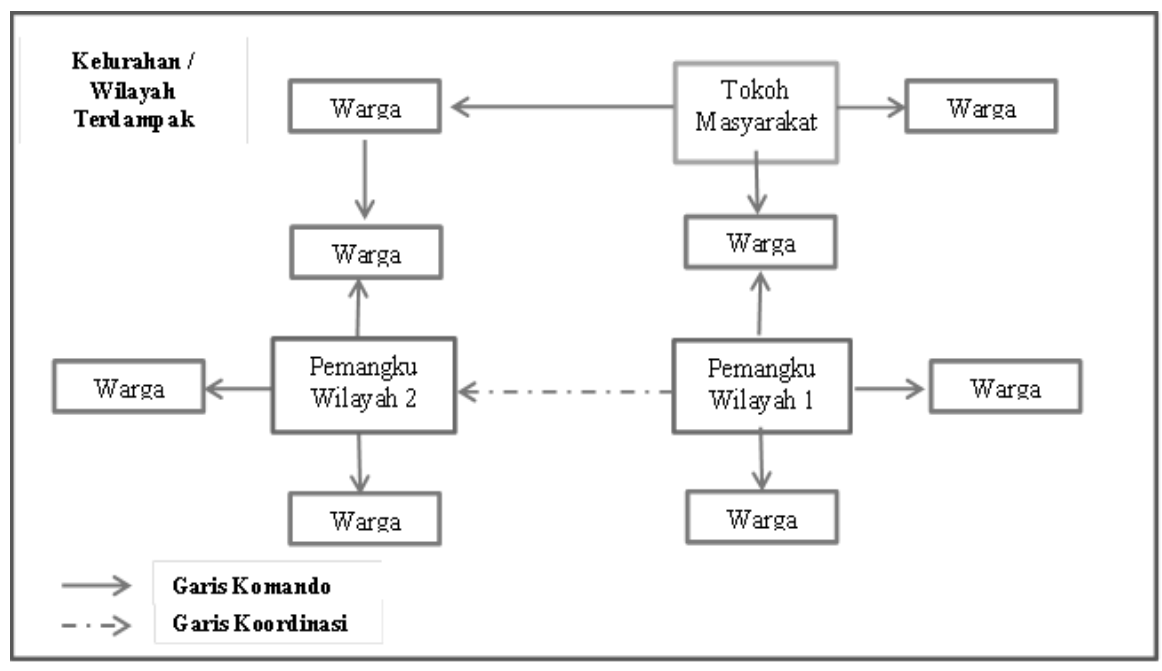

\section{Gambar 1. Skema Komando Terbentuk Tahun 2010}

Potongan kecil dari kurangnya manajemen kelembagaan tersebut menjadi acuan dalam pembentukan kelembagaan yang baru setelah adanya program FEWS. Setelah adanya program FEWS dibentuk kelembagaan yang bergerak dalam bidang kebencanaan khususnya bencana banjir bandang yaitu Kelompok Siaga Bencana. Kelompok Siaga Bencana dibentuk di masing-masing kelurahan dari 7 Kelurahan yang termasuk dalam kawasan DAS Beringin. Ketua KSB memegang komando penuh dari sekretaris, bendahara, koordinator kelompok area dan bidang bidang di bawahnya. Ketua KSB juga memiliki kewenangan memberikan instruksi kepada warga sekitar

Terkait komunikasi dan koordinasi, Saat bencana banjir bandang tahun 2010, sebenarnya telah terbentuk cara penyebarluasan komunikasi peringatan bencana kepada masyarakat walaupun bersifat spontanitas. Cara penyebarluasan melalui teriak teriak, memukul tiang listrik hingga melalui siaran pengeras suara masjid. Komunikasi dapat dikatakan belum terncana dengan baik dan dirasa kurang efektif. (wawancara KSB Wates). Komunikasi dilakukan atas inisiatif personal tanpa adanya mekanisme penyebarluasan yang disepakati sebelumnya. Cara penyebarluasan di masing masing wilayah berbeda. 


\section{Perubahan Kesiapsiagaan Masyarakat DAS Beringin Kota Semarang...}

Saat bencana banjir bandang tahun 2010 upaya komunikasi tidak hanyadi dalam wilayah melainkan hingga ke luar wilayah. Komunikasi ke luar yang dimaksud adalah komunikasi ke kelurahan maupun ke pihak terkait bencana banjir bandang. Pada saat itu, komunikasi ke pihak kelurahan dilakukan oleh pemangku wilayah/ketua RT/RW (wawancara beringin, wates, mangunharjo). Pada kasus di kelurahan beringin, komunikasi tidak hanya dilakukan oleh pemangku wilayah namun juga dilakukan oleh warga lain (wawancara KSB beringin). Notabene warga yang melapor merupakan warga yang bekerja dan faham di bidang kebencanaan. Kondisi tersebut dimanfaatkan untuk permintahan kebutuhan bantuan. Hal tersebut diungkapkan oleh Pak Saheri selaku ketua KSB Beringin. Info disertai dengan permohoman proposal bantuan sehingga kebutuhan logistik memadai

Cara penyebarluasan saat bencana 2010 menjadi dasar dalam penentuan mekanisme penyebarluasan setelah masuknya program FEWS. Cara cara tersebut tetap akan digunakan dipadukan dengan mekanisme peringatan dini banjir bandang. Penyebarluasan yang bersifat spontanitas berubah menjadi penyebarluasan terncana dan terorganisir. Informasi yang diberikan dan cara penyebarluasan disesuaikan dengan tanda tnda peringatan dini. Alat komiunikasi disepakati terlebih dahulu sebelum dijadikan acuan dalam penyebarluasannya

Mengacu pada penjelasan di atas terdapat perubahan mendasar pada variabel mobilisasi sumber daya. Adapun detail perubahan dapat dilihat pada Tabel 3.

Tabel 3. Poin Perubahan Variabel Mobilisasi Sumber Daya

\begin{tabular}{|c|c|c|c|}
\hline No & Aspek & Pra Program & Pasca Program \\
\hline 1 & $\begin{array}{l}\text { Ketersediaan tim } \\
\text { bencana }\end{array}$ & $\begin{array}{ll}\text { - } & \text { Belum ada tim terkait } \\
\text { penanganan bencana di } 7 \\
\text { kelurahan selain wonosari } \\
\text { - Wonosari telah memiliki tim } \\
\text { penanggulanagn bencana }\end{array}$ & $\begin{array}{l}\text { Terbentuknya Kelompok Siaga } \\
\text { Bencana (KSB) di } 7 \text { kelurahan } \\
\text { yang termasuk dalam kawasan } \\
\text { DAS Beringin } \\
\text { - Terbentuknya KSB kelompok } \\
\text { area di internal KSB kelurahan }\end{array}$ \\
\hline 2 & Prosedur Komando & $\begin{array}{l}\text { - Pemangku Wilayah } \\
\text { - Tokoh masyarakat }\end{array}$ & - Ketua KSB \\
\hline 3 & $\begin{array}{l}\text { Peran } \\
\text { Kelembagaan }\end{array}$ & $\begin{array}{l}\text { - Peran responsif/ reaktif } \\
\text { bencana }\end{array}$ & $\begin{array}{ll}\text { - } & \text { Peran antisipatif bencana } \\
\text { (kesiapsiagaan KSB) } \\
\text { - Peran reaktif bencana (tanggap } \\
\text { darurat KSB) }\end{array}$ \\
\hline 4 & $\begin{array}{l}\text { Struktur } \\
\text { Kelembagaan }\end{array}$ & - Belum ada struktur & $\begin{array}{l}\text { - Struktur terbagi dalam beberapa } \\
\text { bidang dengan diorganisir oleh } \\
\text { Ketua KSB (lihat gambar 4.10) }\end{array}$ \\
\hline 4 & $\begin{array}{l}\text { Skema Komunikasi } \\
\text { dan koordinasi }\end{array}$ & $\begin{array}{l}\text { - Komunikasi bersifat spontanitas } \\
\text { - Komunikasi dilakukan atas } \\
\text { inisiatif beberapa warga } \\
\text { - Koordinasi belum terstruktur }\end{array}$ & $\begin{array}{ll}\text { - } & \text { Komunikasi dan koordinasi } \\
\text { lebih jelas dan terencana } \\
\text { - } \\
\text { Adanya mekanisme komunikasi } \\
\text { dan koordinasi di setiap tanda } \\
\text { peringatan dini. }\end{array}$ \\
\hline 5 & $\begin{array}{l}\text { Kesepakatan } \\
\text { penggunaan alat } \\
\text { komunikasi }\end{array}$ & $\begin{array}{ll}\text { - } & \text { Belum adanya kesepakatan } \\
\text { penggunaan alat } \\
\text { - Komunikasi menggunakan alat } \\
\text { seadanya }\end{array}$ & $\begin{array}{l}\text { Dibuat kesepakatan penggunaan } \\
\text { alat komunikasi di masing } \\
\text { masing wilayah } \\
\text { - Kesepakatan alat berupa } \\
\text { kentongan, dan tiang telkom }\end{array}$ \\
\hline 6 & $\begin{array}{l}\text { Manajemen } \\
\text { komunikasi dalam } \\
\text { dan luar wilayah }\end{array}$ & $\begin{array}{ll}\text { - } & \text { Peran komunikasi berada di } \\
\text { tangan pemangku wilayah / } \\
\text { Ketua RT/RW } \\
\text { - Komunikasi ke luar dilakukan } \\
\text { oleh pemangku wilayah dan } \\
\text { inisiatif beberapa warga } \\
\end{array}$ & $\begin{array}{l}\text { Komunikasi berada pada ketua } \\
\text { KSB dan bidang komunikasi }\end{array}$ \\
\hline
\end{tabular}




\section{Sistem Peringatan Dini Banjir Bandang}

Sebelum adanya program FEWS atau saat terjadinya banjir bandang tahun 2010, masyarakat belum memiliki sistem peringatan dini (wawancara KSB Wates, Beringin,) namun sudah menggunakan gejala alam sebagai peringatan dininya. Peringatan dini dari kearifan lokal dilihat dari intensitas curah hujan, ketinggian air dari bibir sungai dan kondisi sawah warga. Ditinjau dari intensitas curah hujan, jika curah hujan yang tinggi atau deras berlangsung lama (berlangsung selama 2 jam lebih) maka masyarakat akan mulai melakukan persiapan.

Ditinjau dari ketinggian air dari bibir sungai, semakin tinggi air mendekati bibir sungai dan berlangsung dengan rentang waktu yang sangat singkat (yaitu kurang dari 1 jam) maka warga sudah bersiap siap mengevakuasi barang barangnya. Terdapat pemantau sungai yang menginformasikan kepada pemangku wilayah (RT atau RW) terkait situasi ketinggian sungai. Acuan pengamatan lebih bersifat tradisional tanpa menggunakan alat ukur ketinggian muka air.

Dilihat dari kondisi sawah warga, jika air mulai memasuki areal persawahan warga maka warga bersiap berevakuasi. Kondisi tersebut dikarenakan letak sawah yang berada di bawah jalan namun berada sejajar dengan bibir sungai sehingga sebelum air meluap ke jalan dan lingkungan permukiman maka air telah memasuki areal persawahan menandakan volume air cukup tinggi.

Pada kasus di Kelurahan Mangunharjo, KSB Mangunharjo menyatakan jika sudah ada peringatan dini pada tahun 2010. Diungkapkan jika peringatan dini dilihat dari ketinggian muka air dengan patokannya adalah jembatan (wawancara KSB Mangunharjo). Tim yang bertugas memantau adalah dari remaja setempat diawali sejak turunnya hujan deras. Dari semua kasus di semua wilayah menunjukkan peringatan dini bersifat manual tradisional. Belum ada peringatan dini secara teknologi di ketujuh kelurahan. Hingga akhirnya berjalannya program FEWS dengan salah satu targetnya ialah pembuatan sistem peringatan dini yang bersifat teknologi (menggunakan alat). Detail alat peringatan dini yang dipasang adalah alat AWLR (Automatic Water Level Recorder) yang mencatat perubahan ketinggian air sungai dengan selang waktu tertentu, serta alat ARR (Automatic Rain Recorder) yang berfungsi mencatat peningkatan curah hujan yang dapat mengindikasikan potensi banjir.
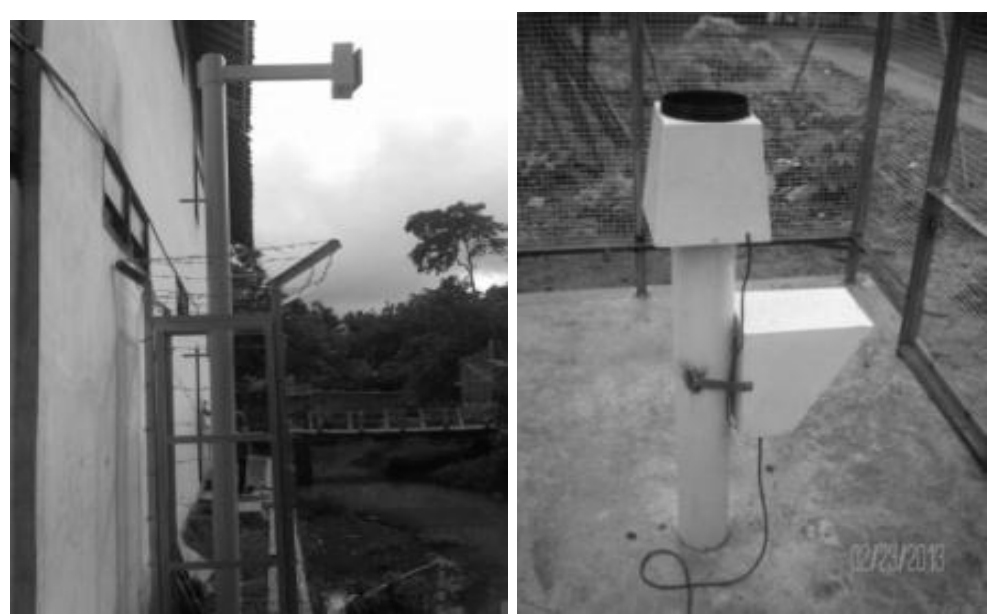

Sumber: DRR-UNDIP, 2013

Gambar 2. Alat AWLR dan ARR 
Terkait mekanisme peringatan dini, Mekanisme peringatan dini pada banjir bandang tahun 2010 belum terorganisir (wawancara KSB Wates). Hampir semua dari ketujuh kelurahan belum memiliki alur informasi dan tindakan dalam mengantisipasi banjir bandang, walaupun komunikasi dan tindakan antisipasi sudah terbentuk. Masyarakat lebih berusaha adaptif daripada antisipatif. Jalur komunikasi belum terbentuk sempurna walaupun di beberapa kelurahan sudah mulai terbentuk seperti di Kelurahan Wates dan Kelurahan Wonosari. Selain itu, belum terdapat informasi awal seperti peringatan bahaya dari pihak BMKG secara langsung kepada pihak masyarakat.

Kondisi tersebut berbeda setelah adanya program FEWS. KSB memiliki peran penting dalam bagian mekanisme peringatan dini. Mengacu pada sistem peringatan dini banjir manual maupun teknologi, didapat input awal yang kemudian diteruskan menjadi sebuah informasi dan tindakan.Demi memaksimalkan sistem peringatan dini, perlu ditentukan pelaku kunci di dalamnya. Pelaku yang memberi kontribusi besar dalam berjalannya mekanisme peringatan dini. Mengingat peringatan awal berada di bagian hulu maka pelaku kunci dalam mekanisme peringatan dini ialah KSB Wates

Berdasarkan penjelasan dari sistem peringatan dini dan mekanisme peringatan dini, bahwa ada peningkatan dalam hal peringatan dini. Terjadi perubahan signifikan dari penggunaan alat manual dan bersifat tradisional menjadi penggunaan peringatan dini berbasis teknologi. Sebelumnya, kejelasan peringatan dianggap kurang karena hanya menggunakan perkiraan. Setelah adanya program FEWS, peringatan menjadi lebih jelas karena tidak hanya menggunakan perkiraan namun juga menggunakan alat. Semua detil perubahan dapat dilihat pada Tabel 4.

Tabel 4. Poin Perubahan Variabel Sistem Peringatan Dini Banjir

\begin{tabular}{l|l|l|ll}
\hline \multicolumn{1}{c|}{ No } & \multicolumn{1}{|c|}{ Aspek } & \multicolumn{1}{c}{ Pra Program } & \multicolumn{1}{c}{ Pasca Program } \\
\hline 1 & Sistem Peringatan Dini & $\bullet \begin{array}{l}\text { Sistem yang terbentuk bersifat } \\
\text { tradisional }\end{array}$ & $\begin{array}{l}\text { Sistem peringatan bersifat } \\
\text { teknologi dan manual }\end{array}$ \\
\hline 2 & Alat peringatan dini & $\begin{array}{l}\bullet \text { Belum ada alat peringatan dini } \\
\text { Hanya menggunakan patokan } \\
\text { benda }\end{array}$ & $\begin{array}{l}\text { Adanya alat peringatan dini } \\
\text { berupa AWLR dan ARR } \\
\text { Adanya alat pendukung } \\
\text { yaitu papan TMA }\end{array}$ \\
\hline 3 & $\begin{array}{l}\text { Mekanisme peringatan } \\
\text { dini }\end{array}$ & $\begin{array}{l}\text { Belum ada mekanisme } \\
\text { peringatan } \\
\text { Peringatan bersifat spontanitas }\end{array}$ & $\begin{array}{l}\text { Terdapat mekanisme } \\
\text { peringatan dini yang jelas di } \\
\text { setiap tanda peringatan dini }\end{array}$ \\
\hline
\end{tabular}

\section{Perencanaan Kesiapsiagaan}

Proses penyelamatan pada banjir pada tahun 2010 masih bersifat spontan atau tiba tiba. Proses penyelamatan tidak terorganisir dengan baik dan terkesan sekadarnya. Pernyataan tersebut dikuatkan oleh KSB mangunharjo jika penyelamatan secara tiba tiba dan kurang efektif dari segi peralatan dan perlengkapan. Penyelamat berinisiatif untuk terjun langsung tanpa komando dan tanpa menggunakan perangkat penyelamatan yang lengkap. Kejadian yang tiba tiba dan ktidaksiapan masyarakat berdampak pada proses penyelamatan yang sekedarnya saja. Penyelamat pada waktu itu (2010) belum terlatih dengan baik (d.1/WC/KSB/03). Penyelamatan menggunakan barang seadanya. Sepeti penggunaan batang pohon pisang dalam penyelamatannya. Selain itu juga menggunakan tali tambang seadanya. Penyelamat juga belum terlatih dengan baik dan kurang mengetahui cara penyelamatan yang benar. Dapat disimulkan jika proses penyelamatan pada waktu 2010 belum sesuai dengan standar prosedur penyelamatan.

Semua kondisi di atas mengalami perubahan setelah berjalannya program FEWS. Setelah adanya program, proses penyelamatan lebih terencana dan terorganisir. Telah 
dibentuk tim bidang penyelamatan dan evakuasi yang didalamnya adalah orang orang terlatih. Selain itu, dibuat penentuan penanggung jawab kelompok rentan. Maksudnya ialah, tim penyelamat bertanggung jawab untuk menyelamatkan dan mengevakuasi kelompok rentan (lansia, balita, difabel) pada saat terjadinya banjir. Proses penyelamatan oleh tim sudah terorganisir dan telah dibuat mekanisme penyelamatan sejak munculnya peringatan awal. Setelah adanya program FEWS, proses penyelamatan dilatih dengan standar penyelamatan yang benar. Tim penyelamat diberikan pelatihan mendalam tentang penyelamatan dengan tepat dan sigap. Tim penyelamat diberikan arahan tata cara mengevakuasi korban hanyut dengan prosedur keamanan dan penggunaan alat alat penyelamatan yang sesuai. Selain itu, KSB diberikan akomodasi standar perlengkapan penyelamatan.seperti life jacket, pelampung untuk korban dan tali tambang.

Ditinjau dari segi evakuasi, proses evakuasi pada banjir 2010 cenderung spontan dan tidak teratur. Secara naluri warga mengungsi ke tempat tempat yang dianggap aman. Sehingga lokasi pengungsian tersebar dan belum terpusat. Evauasi warga berlangsung tergesa gesa sehingga tidak mampu mengamankan barang barang berharga terlebih dahulu. Bahkan di Kelurahan Wonosari, warga melakukan evakuasi dari atap rumah ke atap rumah lainnya dengan menggunakan tangga. Ketinggian air yang tinggi memaksa warga menuju ke atap rumah untuk menghindari terjangan banjir bandang. Sedangkan proses evakuasi di Kelurahan lainnya hampir sama yaitu melaui jalan dan lebih mudah teridentifikasi dibandingkan dengan kondisi evakuasi di Kelurahan Wonosari.

Masyarakat memilih ke lokasi yang lebih tinggi dan tidak berada pada 1 titik pusat (d.4/WC/WA/02). Pada saat bencana, terdapat beberapa lokasi evakuasi dan menyebar dalam satu wilayah. Lokasi evakuasi berada di rumah warga dan tempat ibadah. Sehingga cakupan warga hanya beberapa orang saja. Dari segi kelengkapan, beberapa tempat evakuasi kurang lengkap sarana dan prasarananya. Bahkan ada lokasi evakuasi yang berada di tengah tengah banjir bandang sehingga warga terjebak di lokasi evakuasi tersebut. Lokasi tersebut berada di Kelurahan Wates tepatnya di MI Darul Ulum, dan Kelurahan Wonosari tepatnya di RT 02/ RW 06. Peristiwa di Kelurahan Wonosari memaksa warga mengevakuasi di atap rumahnya masing masing . Lalu berkumpul menuju atap rumah yang lebih tinggi menggunakan tangga.

Setelah adanya program FEWS, proses evakuasi menjadi perhatian khusus dalam implementasi program. Evakuasi lebih terorganisir, dan terencana (d.5/WC/KSB/01). KSB diberikan pelatihan evakuasi dan difasilitasi mengenai alat alat evakuasi. Secara kelembagaan dibentuk bidang evakuasi dan penyelamatan dan diisi oleh orang orang terlatih. Semua detil perubahan dapat dilihat pada Tabel 5.

Tabel 5. Poin Perubahan Variabel Perencanaan Kesiapsiagaan

\begin{tabular}{c|l|ll|l}
\hline No & \multicolumn{1}{|c|}{ Aspek } & \multicolumn{1}{c|}{ Pra Program } & \multicolumn{1}{c}{ Pasca Program } \\
\hline 1 & Kondisi penyelamatan & $\bullet \begin{array}{l}\text { Penyelamatan bersifat } \\
\text { spontanitas dan tidak } \\
\text { terorganisir }\end{array}$ & $\begin{array}{l}\text { Penyelamatan dibuat lebih } \\
\text { terencana dan terorganisir } \\
\text { Telah tersedia mekanisme } \\
\text { penyelamatan }\end{array}$ \\
\hline 2 & $\begin{array}{l}\text { Ketersediaan alat } \\
\text { penyelamatan }\end{array}$ & $\bullet$ & Alat seadanya dan sekedarnya & $\bullet \begin{array}{l}\text { Tersedia alat penyelamatan } \\
\text { seperti tali, life jacket hingga } \\
\text { ban pelampung }\end{array}$ \\
\hline 3 & Lokasi evakuasi & $\begin{array}{l}\text { Lokasi evakuasi acak/tersebar } \\
\text { Sarana dan prasarana kurang } \\
\text { memadai }\end{array}$ & $\begin{array}{l}\text { Ditentukan lokasi evakuasi } \\
\text { baru yang lebih memadai } \\
\text { Lokasi evakuasi diakomodasi } \\
\text { sarana dan prasarananya }\end{array}$ \\
\hline 4 & Rute Evakuasi & $\begin{array}{l}\text { Rute evakuasi kurang terarah } \\
\text { Belum ada jalur evakuasi }\end{array}$ & $\bullet \begin{array}{l}\text { Rute evakuasi lebih terarah } \\
\text { dan lebih aman }\end{array}$ \\
\hline
\end{tabular}


Perubahan Kesiapsiagaan Masyarakat DAS Beringin Kota Semarang...

\begin{tabular}{c|l|l|l}
\hline No & \multicolumn{1}{|c|}{ Aspek } & \multicolumn{1}{c}{ Pra Program } & \multicolumn{1}{c}{ Pasca Program } \\
\hline & & $\begin{array}{l}\text { (Berada di Kelurahan } \\
\text { Wonosari) }\end{array}$ & $\bullet \begin{array}{l}\text { Telah ada pembuatan jalur } \\
\text { evakuasi di wonosari }\end{array}$ \\
\hline 5 & Rambu Evakuasi & $\begin{array}{l}\text { Belum ada rambu penunjuk } \\
\text { evakuasi }\end{array}$ & $\begin{array}{l}\text { Tersedia rambu penunjuk } \\
\text { evakuasi }\end{array}$ \\
\hline 6 & $\begin{array}{l}\text { Kondisi pertolongan } \\
\text { pertama }\end{array}$ & $\begin{array}{l}\text { Pertolongan pertama } \\
\text { sekedarnya }\end{array}$ & $\begin{array}{l}\text { Terdapat perlengkapan } \\
\text { pertolongan pertama }\end{array}$ \\
\hline
\end{tabular}

\section{Kesimpulan dan Rekomendasi}

\section{Kesimpulan}

Berdasarkan hasil analisis didapatkan bahwa terjadi perbedaan antara sebelum adanya program FEWS dengan setelah berjalannya program FEWS. Perbedaan cukup mencolok dikarenakan kesiapsiagaan masyarakat saat terjadi bencana banjir 2010 tergolong kurang dan mengalami perubahan drastis dalam beberapa keadaan setelah adanya program FEWS.

Perubahan kesiapsiagaan terjadi pada upaya pemahaman kebencanaan, mobilisasi sumber daya, sistem peringatan dini banjir bandangn dan perencanaan kesiapsiagaan. Dari pemahaman kebencanaan terjadi perubahan pada aspek sumber informasi pengetahuan, aspek paradigma tindakan mitigaif bencana, aspek kapasitas pengetahuan, aspek pengetahuan mengenai risiko, aspek ketersediaan dokumen penilaian risiko, dan aspek kegiatan KSB mengenai penilaian risiko.

Pada upaya kesiapsiagaan terkait mobilisasi sumber daya, perubahan terjadi pada aspek aspek ketersediaan tim bencana, prosedur komando, aspek peran kelembagaan, aspek struktur kelembagaan, aspek skema komunikasi dan koordinasi, kesepakatan penggunaan alat dan manajemen komunikasi ke luar dan dalam wilayah.

Pada upaya sistem peringatan dini banjir bandang, perubahan terjadi pada aspek sistem peringatan dini, alat peringatan dini dan aspek mekanisme peringatan dini. Sedangkan pada upaya perencanaan kesiapsiagaan, perubahan terjadi pada aspek kondisi penyelamatan, aspek ketersediaan alat penyelamatan, aspek lokasi evakuasi dan rute evakuasi, aspek rambu evakuasi dan aspek kondisi pertolongan pertama

Berdasarkan perubahan pada aspek aspek tersebut maka dapat disimpulkan bahwa hasil penelitian telah menjawab dari pertanyaan penelitian. Telah terjadi perubahan kesiapsiagaan setelah berjalannya program FEWS. Perubahan menyeluruh di semua variabel penelitian dan didetailkan dengan temuan aspek perubahan di setiap variabel.

\section{Rekomendasi} berikut:

Dalam penelitian ini rekomendasi yang dapat diberikan oleh peneliti yaitu sebagi

- Memastikan keberlanjutan KSB dengan mengadakan pertemuan rutin,

- Pelatihan kepada masyarakat umum,

- Pendokumentasian riwayat kebencanaan dan aktivitas KSB oleh KSB dan Masyarakat,

- Pelibatan sektor swasta dalam penyempurnaan kebutuhan peralatan manajemen bencana.

\section{Daftar Pustaka}

Mulyanto, HR, dkk. 2012. Petunjuk Tindakan dan Sistem Mitigasi Banjir Bandang. Jakarta: JICA 
Murdiono, Benny. 2008. Peran Serta Masyarakat Pada Penyusunan Rencana Pengelolaan Daya Rusak Sumber Daya Air. Semarang: Universitas Diponegoro

Muta'ali, Lutfi. 2014. Perencaan Pengembangan Wilayah berbasis Pengurangan Risiko Bencana. Yogyakarta: Badan Penerbit Fakultas Geografi UGM

Nugroho, Kharisma,dkk. 2011. Pengurangan Risiko bencana Berbasis Komunitas di Indonesia:Gerakan, Pelembagaan, dan Keberlanjutan. Jakarta: Penerbit.

Picket, S.T.A,dkk. 2003. Resilient cities: meaning, models, and metaphor for integrating the ecological, socioeconomic, and planning realms. Landscape and Urban Planning 69 (2004) 369-384.

Sudibyakto. 2011. Manajemen Bencana Di Indonesia kemana?. Yogyakarta: Gajah Mada university Press

Sugiyono. 2012. Metode Penelitian kuantitatif, Kualitatif, dan $R \& D$. Bandung: Alfabeta

Suryana. 2010. Metodologi Penelitian: Model Praktis Penelitian Kuantitatif dan Kualitatif. Bandung: Penerbit UPI

Teguh Paripurno, Eko. 2009. Pengurangan Risiko Bencana Berbasis Komunitas Dalam Kebijakan Perencanaan, Pendanaan \& Pelaksanaan Pembangunan. 5th National Conference Community Based Disaster Risk Reduction 25-30.

Yanez, Karol. 2012. Visions of Resilient City. EWB-UK, ARUP 
244 Perubahan Kesiapsiagaan Masyarakat DAS Beringin Kota Semarang...

JURNAL WILAYAH DAN LINGKUNGAN, 2 (3), 231-244 